\title{
Fish Community of Cyprinid Family in Serayu River Banyumas Regency
}

\author{
Susanto \\ Universitas Muhammadiyah Purwokerto \\ Susanto280266@gmail.com
}

\begin{abstract}
The purpose of this research is to reveal and describe the fish community, especially the fish community of Cyprinid Family in Serayu River of Banyumas Regency. The study was conducted using a survey method, with purposive random sampling technique. The study was conducted in Serayu River of Banyumas Regency where three major rivers lead to it, namely Klawing River, Logawa River, and Tajum River. The study found that waters quality which includes physical and chemical parameters of waters, namely: temperature, flow velocity, water clarity, dissolved oxygen content and $\mathrm{pH}$, and plankton species variations in Serayu River of Banyumas Regency are in good condition and decent for fish life. Moreover, diversity of fish species in Serayu river of Banyumas Regency is low, however, a dominance of fish species were not founf.Finally, fish community of Cyprinidae Family in Serayu river of Banyumas Regency has the most species variations and individual count and the highest abundance.
\end{abstract}

Keywords: Fish Community, Cyprinid Family, Serayu River

\section{INTRODUCTION}

Whether it has been realized or not, each activity using natural resource may cause disruption that encourage ecosystems change on a certain scale. Watershed on Serayu River is one of 35 watersheds in Central Java, which is included in the critical category [1].

The problem in this research is people who are fishing do not know for sure about fish characters neither the effect of their activities on existing fish stocks, growth, and sustainability of species. Utilization of nonbiological resources from sand and stone mining activity by the inhabitants of Banyumas Regency, especially those living in areas along Serayu River streams can affect the quality of river waters. Furthermore, it will affect the quality of fish communities living in the river.

Management of fishery biological resources in Serayu River is an integrated part of water management. The final goal is an achievement of public welfare. Therefore, to maintain the biological potential of fishery in the waters, research on fish communities of Cyprinidae Family in Serayu river of Banyumas regency need to be done.
The purpose of this research is to reveal and describe the fish community, especially the fish community of Cyprinid Family in Serayu River Banyumas Regency which includes: (1) The water quality which includesphysical and chemical parameters of waters, namely: temperature, flow velocity, water clarity, dissolved oxygen content and $\mathrm{pH}$, and plankton species variations. (2) Diversity and dominance of fish species. (3) community (species variation, count individual, and abundance) of Cyprinid Family

\section{METHOD}

The study was conducted in Serayu River of Banyumas Regency where its streams are three major rivers namely Klawing river, Logawa river, and Tajum river. Sampling of fish and physics-chemistry parameter data and plankton species variations are conducted over two years, the first year of the study (October 2009- July 2010) and the second year of the study (October 2010July 2011) with three months intervals. Sampling was done in the morning until noon (08:00-13:00) and evening (19.00-24.00).

The study was conducted using a survey method, with purposive random sampling technique [2].The research was implemented through fish sampling and measurement of water quality in the form of physical and chemical parameters of waters and plankton species variations performed at each study site. Fish sampling was using fishing gear net and hand web; it was carried 10 times sampling for a net and 10 times sampling for a web at each sampling point. Fish sampling results identified by [3] and verified at the www.FishBase.org.Data analysis was performed to determine the structure of fish communities are Diverse analysis [4].

\section{RESULTS AND DISCUSSION}

\section{Water Quality}

The analysis result of the temperature in the first year of the study (October 2009 - July 2010) obtained range: 27.72 to $29.63{ }^{\circ} \mathrm{C}$ with an average of $28.28 \pm 0.342^{\circ} \mathrm{C}$ and the second year of the study (October 2010 - July 2011 ) in range: 27.63 to 29.86 with an average of $28.51 \pm$ 0.724 . Flow velocity in the first year of research results obtained with the range: 0.26 to $0.87 \mathrm{~m} / \mathrm{s}$ and an average of $0.52 \pm 0.207 \mathrm{~m} / \mathrm{s}$ and the second year of research is about 0.27 to $0.98 \mathrm{~m} / \mathrm{s}$ with an average of $0.54 \pm 0.195$ 
$\mathrm{m} / \mathrm{s}$. The brightness of the water in the first year of research results obtained with the range: 33.75 to 70.00 $\mathrm{cm}$ and an average of $42.49 \pm 11.888 \mathrm{~cm}$ and the second

The analysis result of the dissolved oxygen content in the first year of research results obtained in the range of 5.92 to $8.45 \mathrm{ppm}$ and an average of $6.88 \pm 0.782$ ppm and the second year the study is about 4.20 to 8.23 ppm and an average of $6,04 \pm 1.241 \mathrm{ppm}$. The degree of acidity $(\mathrm{pH})$ in the first year of research results obtained in the range of 6.72 to 7.22 and an average of $6.97 \pm 0.183$ and the second year the study is about 6.72 to 7.22 with an average of $6.97 \pm 0.183$.

Plankton thatobtained during the research identified the species variation based [5];[6]. The identification results show that plankton species variations in Serayu River of Banyumas Regency quite a lot. During the study has identified 109 species of planktons that is included in the 47 Families and 23 Ordos.This amount consists of Phytoplankton are 97 species included in the 36Families and 18 Ordos, and Zooplankton consists of 12 species included in 11 Families and five Ordos.

Based on [7]it shows that the waters in Serayu River of Banyumas Regency are in good condition and suitable for fish life.

\section{Fish species diversity and dominance}

Diverse analysis used to reveal the diversity of fish in the Serayu River of Banyumas Regency in the first year of the study (October 2009 - July 2010) and the second year of the study (October 2010 - July 2011). The Shanon-Wienner diversity index value in the first year study is about 1.364 to 2.395 with an average of $1.899 \pm 0.396$, while the second year the study is about 1.452 to 2.284 with an average of $1.843 \pm$ 0.296.Simpson dominance index value of the first year of research is about 0.0928 to 0.4581 with an average of $0.2462 \pm 0.1372$, while the second year of the study is about 0.1338 to 0.3457 with an average of $0.2731 \pm$ 0.0763 . The results of the analysis of fish diversity diverse between first year and second year study, they showed a low value, more data is shown in Table 1.

Table 1. The diverse analysis result of diversity of fish in the first year and the second year of the study (A), the diverse analysis result to fish species dominance in the first year and the second year of the study (B).

Remarks: $\mathrm{S}=$ species count, $\mathrm{N}=$ average individual count, $\mathrm{H}^{\prime}=$ Shanon Wiener Index, $\mathrm{D}=$ Simpson domination index.

The diverse analysis result revealed that diversity of fish in the first year and the second year of research and fish species dominance is low. The condition means that although there are no fish species dominance, however, the presence of fish in the Serayu River of Banyumas Regency in worrisome condition.

\section{Fish Community of Cyprinid Family}

\section{a. Species variations and individual count of fish}

Research began in October 2009 until July 2011, is divided into two years of research, the first year of the study (October 2009 - July 2010) and the second year of the study (October 2010 - July 2011). Sampling is year of the study is about 24.05 to $61.75 \mathrm{~cm}$ and an average of $33.71 \pm 11.676 \mathrm{~cm}$.

conducted with three months intervals from day and night in three locations and nine research stations along Serayu River of Banyumas Regency. Individual count of fish which successfully obtained was 3,871 fishes included in 29 species, 20 Families, and 11 Ordos.

\begin{tabular}{|c|c|c|c|c|c|c|}
\hline \multirow{2}{*}{ Station } & \multicolumn{3}{|c|}{ Year I } & \multicolumn{3}{c|}{ Year II } \\
\cline { 2 - 7 } & S & N & $\mathbf{H}^{\prime}$ & S & N & $\mathbf{H}^{\prime}$ \\
\hline L1S1 & 16 & 45 & 2,065 & 14 & 49 & 1,672 \\
\hline L1S2 & 15 & 56 & 2,395 & 16 & 89 & 2,284 \\
\hline L1S3 & 12 & 64 & 1,362 & 18 & 107 & 2,125 \\
\hline L'2S1 & 17 & 47 & 2,248 & 14 & 64 & 1,585 \\
\hline L2S2 & 16 & 29 & 2,305 & 12 & 35 & 1,882 \\
\hline L2S3 & 16 & 46 & 2,024 & 15 & 69 & 1,920 \\
\hline L3S1 & 18 & 98 & 1,907 & 17 & 128 & 1,452 \\
\hline L3S2 & 20 & 111 & 1,422 & 16 & 93 & 1,522 \\
\hline L3S3 & 18 & 101 & 1,364 & 19 & 142 & 1,759 \\
\hline All Locations & 26 & 66 & 2,105 & 29 & 86 & 2,231 \\
\hline
\end{tabular}

(A)

\begin{tabular}{|c|c|c|c|c|c|c|}
\hline \multirow{2}{*}{ Station } & \multicolumn{3}{|c|}{ Year I } & \multicolumn{3}{c|}{ Year II } \\
\cline { 2 - 7 } & $\mathrm{S}$ & $\mathrm{N}$ & $\mathrm{D}$ & $\mathrm{S}$ & $\mathrm{N}$ & $\mathrm{D}$ \\
\hline L1S1 & 16 & 45 & 0,1896 & 14 & 49 & 0,2453 \\
\hline L1S2 & 15 & 56 & 0,0928 & 16 & 89 & 0,1338 \\
\hline L1S3 & 12 & 64 & 0,3947 & 18 & 107 & 0,1568 \\
\hline L2S1 & 17 & 47 & 0,1367 & 14 & 64 & 0,3220 \\
\hline L2S2 & 16 & 29 & 0,1013 & 12 & 35 & 0,1873 \\
\hline L2S3 & 16 & 46 & 0,1839 & 15 & 69 & 0,2150 \\
\hline L3S1 & 18 & 98 & 0,2319 & 17 & 128 & 0,3110 \\
\hline L3S2 & 20 & 111 & 0,4421 & 16 & 93 & 0,3457 \\
\hline L3S3 & 18 & 101 & 0,4581 & 19 & 142 & 0,2885 \\
\hline All Locations & 26 & 66 & 0,2308 & 29 & 86 & 0,1658 \\
\hline
\end{tabular}

Species variations that successfully obtained in this study is more when compared to the result of previousresearch conducted by [8] found 15 species in the Serayu River upstream of Wonosobo. [9] obtained 20 species in the Enim River of Muara Enim South Sumatera Regency. [10] found eight species in the Cidanau River Banten. [11] nine species in the Comal River of Pemalang Regency. The most of species variations during the study are members of Family Cyprinid, there areseven species.

The highest individual count of fish in the first year and second year of the research are members of Family Cyprinidae,respectively:794 fishes (55.23\%) and 941 fishes $(38.65 \%)$. The lowest individual count of fish in the first year of study is Anguilloidae Family members, 
that is two fishes $(0.13 \%)$, while the lowest individual count of fish in the second year of study is Claridae Family members and Synbhrachidae Family that each one fish $(0.03 \%$ and $0.06 \%)$.

\section{Abundance}

three locations (at mouth of Tajum River in Serayu River) with an average abudance is 103.17 fish pcu and 120.83 fish pcu. Another location (the mouth of Klawing River in Serayu River) has an average abundance 40.42 fish pcu and 56.08 fish pcu.

Figure 1 shows the average value of the fish abundance in each location and research stations in the first year and the second year of the study. The highest average of fish abundance during study period contained in the location three of three stations, that is $142,25 \mathrm{pcu}$ (second year of study) and the lowest abundance were in the location two of second station at 28.75 pcu (first year of study). The abundance much influenced by environmental condition and suitability of fishing gear. Differences of river environmental condition scan bring out the difference of fish abundance. The larger the size of river, the greater amount and diversity of fish species. Other factors that influence the level of fish abundance is the fertility waters, climate, season, factors of physical and chemical water [12];[13].

The average of fish abundance in each Family obtained the Cyprinidae Family is the highest, that is $37,93 \mathrm{pcu}$ in the first year of study and 38,14 pcu in the second year of study. Fish abundance based by Family presented more detail in Figure 2.

Rasboralateristriata is known species by local names Lunjar Andong, these species were found with the highest abundance. The abundance value for $R$. Lateristriata is $30.28 \mathrm{pcu}$ in the first year of study and $27.31 \mathrm{pcu}$ in the second year of study. The result in accordance with the research result of [8] $R$. lateristriata and B. Gonoinotus species is Cyprinidae Family membersand the two predominant species among the 15 species of fish which found in the Serayu upsteam River in Wonosobo Regency, Jawa Tengah.

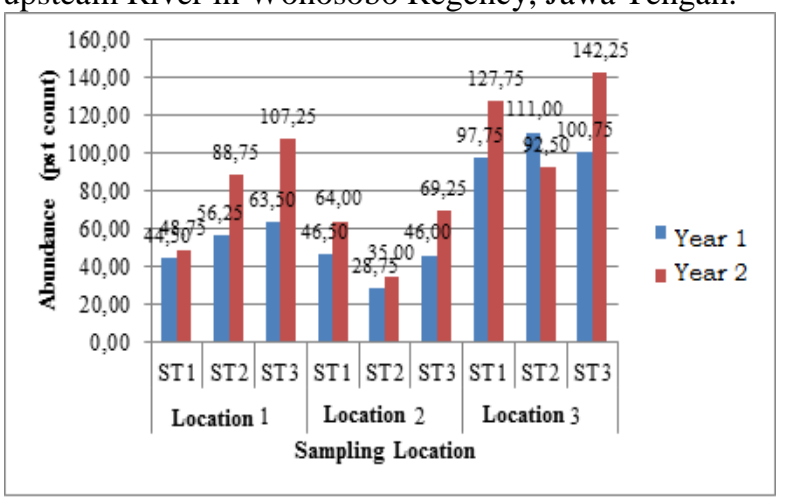

Figure 1. Average of fish abundance in the first year and secon year of study
The abundance of fish in this study expressed in per caught unit (pcu), which is 10 times sampling with fishnet and 10 times sampling with hand web. The highest fish abundance in the first year and the second year of study found at the

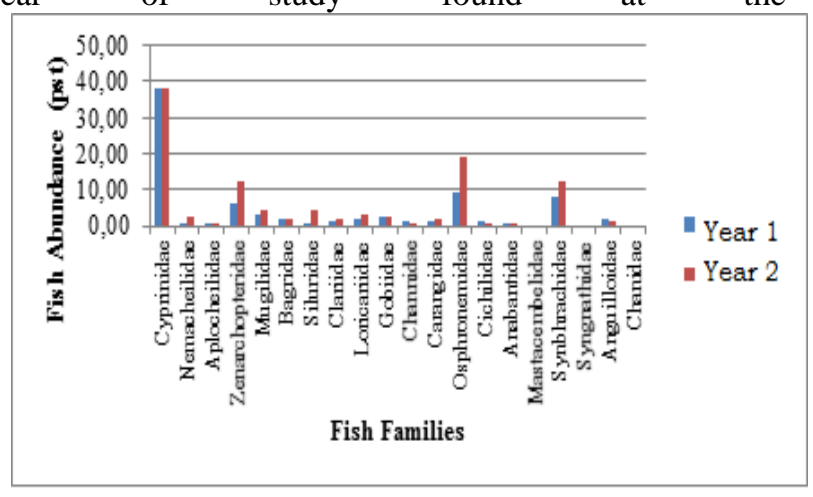

Figure 2. Average of fish abundance based on Family, first year and second year of study.

\section{CONCLUSION}

The conclusions based on result and discussion are:

Waters quality which includes physical and chemical parameters of waters, namely: temperature, flow velocity, water clarity, dissolved oxygen content and $\mathrm{pH}$ and plankton species variations in Serayu river of Banyumas Regency is in good condition and decent for fish life.

Diversity of fish species in Serayu river of Banyumas Regency is low, however, a dominance of fish species are not found.

Fish community of Cyprinidae Family in Serayu River of Banyumas Regency have the most species variations and individual count and the highest abundance.

\section{REFERENCES}

[1] Yuwono, P. B. Tiga Puluh Lima Daerah Aliran Sungai di Jawa Tengah Kritis. Kompas, 13 Februari 2014. Halaman : 21.2014.

[2] Mantra, I. B. dan Kasto.Penentuan Sampel, dalam Metode Penelitian Survey. Masri Singarimbun dan Sofian Effendi (Ed). LP3ES. Jakarta.1989.

[3] Kottelat, M., J. A. Whitten, S. N. Kartikasari, Wirjoatmojo. Ikan Air Tawar Indonesia Bagian Barat dan Sulawesi. Edisi Dwi Bahasa Inggris Indonesia. Periplus Edition. Jakarta.1993.

[4] Clarke, K. R. and R. M. Warwick..Changes in Marine Communities : an Approach to Statistical Analysis and Interpretation, $2^{\text {nd }}$ edition, PRIMER-E: Plymouth, London.2001

[5] Sachlan, M. Planktonologi. Fakultas Peternakan dan Perikanan, Universitas Diponegoro. Semarang.1982.

[6] Anonymous. Water Quality Monitoring. A Practical Guide to the Design an Implementation of Freshwater Quality Studies 
and Monitoring Programms. E\&FN Spon an Imprint of Chapman \& Hall, 2 - 6 Boundary Row. London SE1 8HN. United Kingdom.1996.

[7] Peraturan Pemerintah Republik Indonesia. Nomor 82 Tahun 2001 tentang :Pengelolaa nKualitas Air danPengendalianPencemaran Air. Sekretariat Negara Replublik Indonesia. Jakarta.2001.

[8] Hadisusanto, S., Tussanti, I. Trijoko. Komunitas Ikan di Sungai Serayu Hulu Wonosobo Jawa Tengah .Prosiding Seminar Nasional Keanekaragaman Hayati Ikan. Pusat Penelitian Biologi Lembaga Ilmu Pengetahuan Indonesia. Bogor.2000.

[9] Hamidah, A. Keanekaragaman Jenis Ikan di Sungai Enim Kabupaten Muara Enim Provinsi Sumatera Selatan. Jurna IIktiologi Indonesia, 4 : $51-55.2004$.
[10] Abdurahim, A., S. Wargasasmita, I. S. Soewelo. Kemelimpahan dan Sebaran Longitudinal IkanIkan di Sungai Cidanau, Banten.Jurnal Iktiologi Indonesia, $4: 57$ - 60.2004 .

[11] Susanto dan Suharti. Inventarisasi Jenis-Jenis Ikan yang Ditangkap Menggunakan Jala di Sungai Comal Kecamatan Ampelgading Kabupaten Pemalang.Biomath, 7 : 64 - 71.2006.

[12] Daufresne, M., M. C. Roger, H. Capra and N. Lamouroux. Long term change on invertebrata and fish community in Rhone river down stream : climate factor effect. Global Change Biology, $10: 124-140.2003$.

[13] Merten, E. C., N. A. Hemstad, S. L. Eggert, L. B. Johnson, R. K. Kolka, R. M. Newman and B. Vondracek. 2010. Fish abundance summer temperature and deforestry relationship in North Minnesota flow system from 1997 to 2007. Ecology of Freshwater Fish, 19 : 63 - 73. 